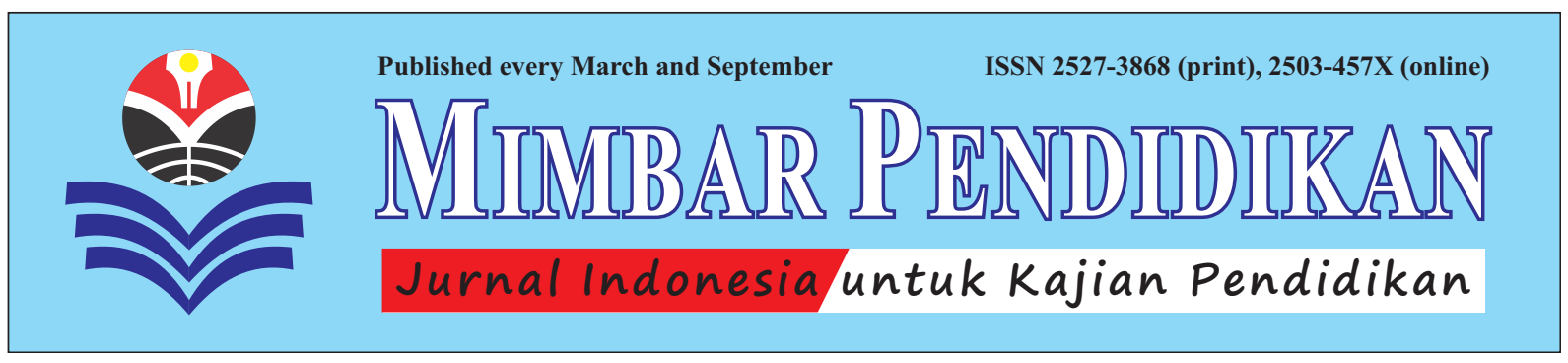

\author{
ROHANA TAN \& NORHASNI ZAINAL ABIDDIN
}

\title{
Tinjauan Permasalahan Akhlak Belia di Institusi Pengajian Tinggi
}

\begin{abstract}
ABSTRAKSI: Belia adalah aset bernilai kepada negara dan menjadi harapan nusa bangsa untuk merealisasikan hasrat menjadi negara maju. Namun, dengan arus globalisasi yang melanda dunia, apa yang berlaku pada hari ini ialah penglibatan belia, termasuklah belia di institusi pengajian tinggi, dalam permasalahan akhlak yang menyimpang daripada nilai-nilai ke-Timur-an dan prinsip Islam, walaupun hakikatnya mereka telah melalui proses pendidikan agama secara formal di sekolah. Ini menimbulkan persoalan: Apakah permasalahan akhlak belia di institusi pengajian tinggi? Penglibatan mereka dalam tingkah-laku yang berisiko seolah-olah memberi petunjuk bahawa pendidikan di sekolah sahaja belum mencukupi untuk membentuk akhlak belia, dan menjadikan Islam sebagai satu cara hidup dalam kehidupan mereka pada hari ini. Justeru itu, artikel ini mengupas tentang konsep belia dan akhlak Islam, permasalahan akhlak belia di institusi pengajian tinggi, dan cara mengatasinya. Dalam konteks negara Malaysia, pembentukan akhlak belia untuk menjadi insan kamil yang cemerlang dan seimbang dari segi intelek dan spiritual adalah proses pendidikan sepanjang hayat dan perlu diberi penekanan selaras dengan pembangunan dan kemajuan negara-bangsa.
\end{abstract}

KATA KUNCI: Belia; Akhlak; Institusi Pengajian Tinggi; Globalisasi; Pendidikan Tidak Formal.

ABSTRACT: "Exploring the Issues of Morality among Youths in Higher Education Institution". Youth is a valuable asset to the nation to realize the objective of becoming a developed nation. However, what is happening in the globalization era nowadays is the involvement of youths, including those in higher educations, in the behaviors that deviate from Eastern values and principles of Islam, despite the fact that they have been through the process of formal religious education in schools. This begs the question: What are the moral problems of youths in institutions of higher education? Their risky behaviors seem to indicate that school education alone is not sufficient to to form good morals in youths, and Islam can alternatively be made a way of life. Therefore, this article explores the concept of youths and Islamic morality, moral problems of youths in institutions of higher education, and how to overcome them. In the context of Malaysia as a nation-state, the development of youths'moral to be a perfect human and who can maintain a balanced in the intellectual and spiritual aspects is a lifelong process in education and should be addressed in line with the development and progress of the nation-state.

KEY WORD: Youths; Morality; Higher Education Institution; Globalization; Informal Education.

About the Authors: Rohana Tan ialah Pelajar Master Sains Pendidikan Pengembangan di Jabatan Pemajuan Profesional dan Pendidikan Lanjutan, Fakulti Pengajian Pendidikan UPM (Universiti Putra Malaysia). Prof. Madya Dato' Dr. Norhasni Zainal Abiddin ialah Pensyarah di Jabatan Pemajuan Profesional dan Pendidikan Lanjutan, Fakulti Pengajian Pendidikan UPM Serdang, Selangor Darul Ehsan, Malaysia. Alamat emel: nonie@upm.edu.my dan nonieza99@gmail.com

How to cite this article? Tan, Rohana \& Norhasni Zainal Abiddin. (2016). "Tinjauan Permasalahan Akhlak Belia di Institusi Pengajian Tinggi” in MIMBAR PENDIDIKAN: Jurnal Indonesia untuk Kajian Pendidikan, Vol.1(2) September, pp.161-178. Bandung, Indonesia: UPI [Indonesia University of Education] Press, ISSN 2527-3868 (print) and 2503-457X (online).

Chronicle of the article: Accepted (February 19, 2016); Revised (May 20, 2016); and Published (September 30, 2016). 


\section{PENDAHULUAN}

Belia adalah aset terpenting dan tunggak kemajuan sesebuah negara. Mereka adalah agen perubahan yang menjadi harapan nusa dan bangsa untuk meneruskan pembangunan dan menentukan nasib masyarakat serta masa depan negara. Maju atau mundur sesebuah masyarakat turut diukur daripada kualiti generasi mudanya pada hari ini.

Sejarah telah membuktikan hakikat ini apabila Nabi Muhammad SAW (Salallahu Alaihi Wassalam) dilantik menjadi Rasul pada usia belia, iaitu 40 tahun. Pada waktu itu, Abu Bakar al-Siddiq sendiri berusia 37 tahun, Umar bin Khattab berusia 27 tahun, Uthman bin Affan berusia 34 tahun, dan Ali bin Abi Talib berusia 13 tahun. Sahabat dan sepupu Nabi, iaitu Jaafar bin Abi Talib sebagai contoh, telah dilantik oleh Nabi menjadi ketua rombongan hijrah dari Mekah ke Habsyah ketika berusia 20 tahun (Ismail, 2005). Bersama-sama sahabat daripada golongan belia yang memiliki keimanan yang teguh dan akhlak yang tinggi, Nabi Muhammad SAW telah menggembeleng tenaga untuk menyebarluaskan Islam dan membangunkan peradaban Islam.

Dalam konteks Malaysia, harapan untuk menjadi negara maju pada tahun 2020 adalah ditentukan oleh generasi belia yang seimbang daripada segi intelek, spiritual, emosi, dan jasmani berasaskan keimanan kepada Allah seperti digariskan dalam Falsafah Pendidikan Kebangsaan (Sang, 2010) dan Dasar Pembangunan Belia Negara (KBS Malaysia, 1997). Ini kerana negara perlu maju, bukan sahaja daripada sudut ekonomi, malah dalam semua aspek merangkumi politik, sosial, spiritual, psikologi, dan budaya (Mohamad, 1991).

Walau bagaimanapun, matlamat Falsafah Pendidikan Negara, Dasar Pembangunan Belia Negara, dan Wawasan 2020 untuk melahirkan modal insan yang holistik tentunya menjadi sukar dan rumit sekiranya golongan belia negara ini, termasuklah belia yang berada di institusi pengajian tinggi, terjebak dengan tingkah-laku negatif dan permasalahan akhlak yang bertentangan dengan nilai-nilai ke-Timur-an dan prinsip Islam (Zakaria, 2009).

Remaja dan Belia. Remaja atau adolescence berasal daripada bahasa Latin, iaitu adolescere, yang bermaksud semakin meningkat kematangan (Rice \& Dolgin, 2008). Ia adalah satu proses perkembangan dan bukannya satu jangkamasa (Suzane, 2002; dan Steinberg, 2011). Proses perkembangan ini merupakan satu proses untuk memantapkan identiti individu dan bermulanya perubahan-perubahan pada tubuh, badan, kematangan dalam berfikir, perkembangan emosi, penyesuaian diri kepada kehidupan bermasyarakat, dan kesediaan untuk berperanan sebagai orang dewasa (Ingersoll, 1989; dan Steinberg, 2011).

Manakala G. Stanley Hall, sepertimana dipetik oleh A. Muhd Mansur \& M.T. Siti Nordinar (1992), menjelaskan bahawa remaja adalah satu tempoh atau waktu yang penuh dengan konflik dan masalah (Mansur \& Nordinar, 1992). Malah G. Stanley Hall turut menjelaskan bahawa alam remaja diakhiri dalam lingkungan umur 22 hingga 25 tahun (dalam Mansur \& Nordinar, 1992).

Kenneth Keniston (1971) pula menekankan tentang keperluan dan perkembangan belia dan remaja yang dinamakan "budaya belia" atau youth culture (Keniston, 1971). Kenneth Keniston mendefinisikan belia sebagai bukan lagi remaja, tetapi belum dewasa. Belia bukanlah bemakna tamatnya suatu tahap perkembangan, tetapi merupakan satu peringkat transisi, iaitu peralihan yang bersambung daripada dunia remaja kepada alam dewasa. Dalam konteks pelajar universiti, Kenneth Keniston menggambarkan bahawa golongan ini terpisah dalam beberapa keadaan dengan masyarakat dewasa. Sebahagian mereka lebih suka menganggap diri mereka masih berada dalam alam remaja, manakala yang lainnya sudah berada pada tahap belia muda atau 
young adults (Keniston, 1971).

F.P. Rice \& K.G. Dolgin (2008) lebih menekankan remaja mengikut tahap usia dengan membahagikan kepada tiga peringkat, iaitu awal remaja merujuk kepada individu berusia 11 hingga 14 tahun; pertengahan remaja dengan merujuk kepada individu berusia 15 hingga 17 tahun; dan akhir remaja bagi individu berumur 18 tahun hingga 20 tahun (Rice \& Dolgin, 2008). H.K. Khadijah (1994) pula turut membahagikan remaja kepada tiga peringkat, tetapi mengikut perbezaan usia antara perempuan dan lelaki berdasarkan kematangan organ seksual, perubahan fizikal, perkembangan emosi, dan intelek. Peringkat pertama ialah awal remaja (early adolescence) lelaki, antara 10 hingga 15 tahun dan perempuan pula antara 9 hingga 12 tahun; diikuti peringkat pertengahan remaja (middle adolescence), iaitu lelaki antara 14 hingga 18 tahun dan perempuan 13 hingga 17 tahun; dan seterusnya peringkat peringkat akhir remaja (late adolescence), ialah bagi lelaki antara 19 hingga 24 tahun dan perempuan pula antara 18 hingga 23 tahun (Khadijah, 1994).

Menurut Pelan Program Strategik Belia Komenwel, belia dikategorikan sebagai individu berumur 15 hingga 29 tahun. ${ }^{1}$ Pertubuhan Bangsa-bangsa Bersatu pula mentafsirkan belia daripada kalangan mereka yang berumur 15 hingga 25 tahun. $^{2}$ Di Malaysia, Dasar Pembangunan Belia Kebangsaan mendefinisikan belia sebagai individu yang berumur antara 15 hingga 40 tahun ( $c f$ KBS Malaysia, 1997; dan Shahrudin, Azman \& Mazlan, 2010).

Lingkungan umur yang ditetapkan oleh Malaysia ini disifatkan sebagai economically

${ }^{1}$ Lihat "Commonwealth Youth Programme Strategic Plan, 2008 - 2012". Wujud dalam online di: http:// www.thecommonwealth.org/files/229253/FileName/ CommonwealthYouthProgramme StrategicPlan2008-2012. pdf [diakses di Serdang, Malaysia: 14 Februari 2016].

${ }^{2 " U N E S C O}$ (United Nations for Education, Social and Cultural Organization". Wujud dalam online di: http://www. unesco.org/new/en/social-and-human-sciences/themes/ youth/ [diakses di Serdang, Malaysia: 17 April 2016]. active bertujuan memasukan mereka dalam program pembangunan yang sama (Ismail, 2005; dan Sarjit \& Zal, 2008). Walau bagaimanapun, aktiviti dan program pembangunan belia di negara ini lebih memberi fokus kepada belia dalam usia 18 hingga 25 tahun (KBS Malaysia, 1997; Faizah, 2007; dan Razali \& Sarjit, 2010).

Menurut M. Mohd Ismail (2005), program pembangunan belia perlu mengambil kira kelompok belia mengikut faktor umur serta status hidup mereka; dan ia dibahagi kepada lima kelompok:

Pertama, belia remaja, iaitu belia yang masih di bangku sekolah. Belia pada peringkat ini perlu ditekankan dengan pendidikan nilai, pembentukan jati diri, dan pendedahan kepada senario yang berubah dan impaknya ke atas mereka.

Kedua, belia institusi pengajian tinggi, iaitu 18 hingga 25 tahun. Belia dalam kumpulan ini mula memasuki alam yang lebih bebas daripada kawalan ibu bapa dan peraturan sekolah. Belia pada peringkat ini perlu ditekankan dengan penghayatan nilai moral yang tinggi dan memupuk hubungan sihat dalam pergaulan.

Ketiga, belia awal pekerjaan, iaitu 18 hingga 23 tahun. Belia dalam kumpulan ini memerlukan pendedahan pelbagai peluang pekerjaan untuk memajukan diri mereka. Program yang dapat meningkatkan kesedaran sosial yang sihat perlu dilaksanakan ke atas mereka.

Keempat, belia industry, iaitu 20 hingga 30 tahun. Belia dalam kumpulan ini perlu diberi peluang meningkatkan kemahiran diri dalam pekerjaan dan pembangunan insan. Gerakan dan usaha memulihkan imej pekerja industri perlu diberi penekanan dengan meletakan mereka pada posisi yang lebih baik dalam masyarakat dan kehidupan sosial.

Kelima, belia veteran, iaitu 30 hingga 40 tahun. Belia pada peringkat ini telah berumah tangga dan lebih memberi perhatian kepada usaha menambah pendapatan keluarga serta pendidikan anak-anak. Program 
pembangunan belia pada peringkat ini perlu tertumpu kepada usaha meningkatkan kualiti hidup dan pengukuhan institusi kekeluargaan (Ismail, 2005).

\section{Remaja dan Belia daripada Perspektif}

Islam. Remaja dan belia daripada perspektif Islam dibahagi kepada dua peringkat, iaitu peringkat selepas bermimpi yang usianya bermula pada 12 tahun atau 13 tahun sehingga ke usia 21 tahun; dan peringkat kedua iaitu peringkat kematangan bermula daripada usia 22 tahun hingga 30 tahun (cf Nashih, 1989; dan Razaleigh \& Tarmizi, 2010). Menurut U. Abdullah Nashih (1998), peringkat pertama dianggap belia iaitu bermula daripada tahap baligh (sampai umur untuk dipertanggungjawabkan dalam hal ehwal agama) hingga ke usia 21 tahun. Tanda baligh bagi seseorang individu dapat dilihat berdasarkan lima tanda, iaitu tiga bagi lelaki dan dua bagi wanita. Bagi lelaki iaitu bermimpi (keluar air mani), pertumbuhan fizikal tubuh badan, dan bersuara garau atau kasar; manakala bagi perempuan, dua tanda iaitu apabila datang haid atau mengandung (Nashih, 1998).

Golongan belia sangat disanjung dan diberi penghormatan yang tinggi dalam Islam, sehingga Al-Qur'an telah merakamkan kisah sekumpulan belia yang tegas mempertahankan keimanan, seperti dalam surah $A l-K a h f$, ayat 13, berikut ini:

Sesunguhnya mereka itu adalah pemudapemuda yang beriman kepada Tuhan mereka dan Kami tambahkan kepada mereka petunjuk (dalam JPM Malaysia, 1983).

Menurut sejarah Islam, perjuangan Nabi Muhammad SAW (Salallahu Alaihi Wassalam) turut didokong kuat oleh golongan belia yang teguh imannya, seperti Jaafar bin Abi Talib, Usamah bin Zaid, Abdullah bin Masud, Abdul Rahman bin Auf, Musab bin Umair, Bilal bin Rabah, dan banyak lagi. Jaafar bin Abi Talib, sebagai contoh, dilantik menjadi ketua rombongan hijrah dari Mekah ke Habsyah ketika berusia 20 tahun. Usamah bin Zaid pula dilantik sebagai panglima tentera Islam ke Palestin ketika berusia 18 tahun. Begitu juga pada zaman berikutnya, Umar bin Abdul Aziz dilantik menjadi Gabenor Madinah pada usia 25 tahun dan menjadi khalifah pada usia 36 tahun (Ismail, 2005). Manakala pada zaman kerajaan Islam Uthmaniah, Muhammad alFateh telah menaiki takhta pada usia 19 tahun dan berjaya menakluk Kota Konstantinopel, yang kini dikenali sebagai Istanbul pada tahun 1453 M (Masehi), iaitu ketika beliau berusia 21 tahun (Hamid, 2011).

Kesimpulannya, tiada definisi yang jelas tentang belia. Berdasarkan pandangan yang dikemukakan, belia adalah satu peringkat transisi antara zaman remaja dan zaman dewasa. Definisi belia turut ditentukan berdasarkan faktor umur.

\section{PEMBANGUNAN BELIA}

Pembangunan belia bermaksud suatu proses perubahan yang membawa kemajuan dan perkembangan dalam pelbagai aspek kehidupan belia dan masyarakat. Ia meliputi pembangunan akhlak, moral dan spiritual, sosial, ekonomi, politik, pendidikan, budaya, perundangan, dan sebagainya (Erikson, 1963; dan Azizan, 1991). Pembangunan belia menjadi agenda penting bagi sesebuah negara.

Pada tahun 2006, dalam Rancangan Malaysia ke-9 (RMK-9), kerajaan Malaysia telah menekankan pembangunan modal insan yang bukan sahaja mempunyai kemahiran saintifik yang canggih, tetapi turut mempunyai nilai moral dan kerohanian yang tinggi dan "berminda kelas pertama" (dalam Abdullah, 2006; dan Sarjit \& Zal, 2008). Sehubungan itu, kerajaan telah memperuntukkan sebanyak RM (Ringgit Malaysia) 5.46 billion untuk pembangunan belia, berbanding RM 4.95 billion dalam Rancangan Malaysia ke-8. Bagi merealisasikan keprihatinan kerajaan, negara telah mengistiharkan tarikh 15 Mei pada 
setiap tahun sebagai "Hari Belia Negara" (Fazilah, 2009).

Pembangunan belia dengan pendekatan pembangunan belia positif sangat penting dalam sesebuah negara, kerana pendekatan ini memberi tumpuan kepada kemahiran, persekitaran, dan tingkah-laku positif seiring dengan pembentukan jati diri, sikap, dan personaliti yang positif untuk menimbulkan keyakinan diri yang tinggi bagi setiap belia dalam mengharungi cabaran hidup mereka (Fazilah, 2009). Pendekatan ini mengambil kira pembangunan belia sebagai satu proses sosial yang melibatkan diri belia, orang dewasa, masyarakat, agensi kerajaan, dan sekolah dalam menyediakan peluang kepada belia untuk meningkatkan minat, kemahiran, dan kebolehan mereka sebagai persediaan menuju alam dewasa.

Pembangunan belia positif pada keseluruhannya melibatkan proses perkembangan fizikal, sosial, dan emosi yang berlaku semasa tempoh remaja. Jelasnya, ia adalah proses di mana golongan muda memperolehi kemahiran kognitif, sosial, dan emosi; serta kebolehan yang diperlukan untuk mengemudi kehidupan (UME, 2005). Ia bermatlamatkan pembangunan positif dan suasana yang membawa kepada kesejahteraan dalam semua domain kehidupan (Benson et al., 1998).

Lapan elemen dalam pembangunan belia positif bagi membolehkan belia mendapat manfaat menerusi pengalaman yang disediakan daripada semua elemen, iaitu seperti berikut: (1) Keselamatan fizikal dan emosi; (2) Suasana kekitaan atau belonging dan kebersamaan atau ownership; (3) Pembangunan nilai diri; (4) Penerokaan potensi diri; (5) Pembinaan hubungan yang berkualiti bersama rakan sebaya dan orang dewasa; (6) Belia boleh membincangkan nilai-nilai yang konflik dalam membentuk diri mereka; (7) Belia merasakan ketelusan yang datang dari pihak berkuasa; serta (8) Belia mengembangkan keupayaan mereka untuk menikmati kehidupan dan memahami bahawa kejayaan bagi mereka adalah sesuatu yang mungkin ( $c f$ UME, 2005; dan Fazilah, 2009).

Kesimpulannya, pembangunan belia yang positif memerlukan keseimbangan antara jasmani, emosi, intelektual, dan rohani atau spiritual. Ia hanya akan berlaku apabila disokong oleh persekitaran yang positif melibatkan belia itu sendiri serta masyarakat merangkumi rakan sebaya, ibu bapa, dan ahli masyarakat yang lain.

Konsep Akhlak. Akhlak bermaksud kelakuan atau tingkah-laku yang baik (DBP Malaysia, 1998). Menurut M.T. Abdul Hafiz, S. Zakaria \& I. Ahmad Munawar (2012) pula, akhlak bermaksud perangai, tabiat, dan budi pekerti (Hafiz, Zakaria \& Munawar, 2012). Imam M. Al-Ghazali (1988) menjelaskan bahawa akhlak merujuk kepada suatu keadaan dalam jiwa (al-nafs) manusia yang tetap dan mantap, yang melahirkan perbuatan dan perlakuan dengan senang dan mudah tanpa perlunya berfikir dan membuat apa-apa pertimbangan lagi ( $c f$ Al-Ghazali, 1988; Zakaria, 2001; Shakirah, 2008; dan Nasir, 2010).

Sekiranya keadaan dan suasana dalaman tersebut memandu seseorang melakukan perbuatan yang baik, seperti amanah, sabar, adil, berani, sederhana, dan sebagainya, maka seseorang itu boleh dikatakan mempunyai akhlak yang baik. Sekiranya berlaku sebaliknya, seseorang itu akan dikatakan tidak berakhlak jika keadaan dan suasana tersebut merealisasikan perbuatan yang jahat, seperti munafik, penakut, zalim, tidak sabar, melampaui batas, dan sebagainya (Nasir, 2010; dan Munawar, Zakaria \& Aishah, 2012).

Oleh itu, akhlak tidak merujuk kepada perbuatan baik atau buruk yang dilakukan oleh seseorang, tetapi ia merujuk kepada dimensi rohaniah yang mendesak seseorang supaya melakukan sesuatu perbuatan, samada baik atau buruk. Akhlak merupakan bahagian dalaman (kejiwaan) seseorang, sementara perbuatan adalah bahagian luaran. Akhlak menjadi penyebab kepada sesuatu perbuatan, manakala perbuatan pula memanifestasikan 
keadaan dan suasana kejiwaan tersebut. Akhlak yang baik merealisasikan tingkahlaku yang baik; dan akhlak yang buruk merealisasikan tingkah-laku yang keji dan tidak bermoral ( $c f$ Argue, Johnson \& White, 1999; dan Nasir \& Ibrahim, 2011).

Akhlak dalam kajian ini adalah merujuk kepada tingkah-laku luaran yang selaras dengan ajaran Islam dengan melakukan perbuatan yang baik (makruf) dan meninggalkan kemungkaran, iaitu perkara yang dilarang seperti yang digariskan dalam Al-Qur'an dan Sunnah Rasulullah Sallahu Alaihi Wassalam, iaitu Nabi Muhammad (Jamiah et al., 2004; Azhar, 2006; dan Zakaria, Munawar \& Fatah, 2012).

Pada dasarnya, akhlak Islam adalah bersumberkan Al-Qur'an dan Al-Sunnah. Konsep akhlak yang dijelaskan dalam $\mathrm{Al}$ Qur'an, bukan sahaja untuk difahami, tetapi untuk dilaksanakan. Contoh akhlak dalam Islam ialah akhlak Rasulullah SAW (Sallahu Alaihi Wassalam) merangkumi segenap dimensi kehidupan, seperti firman Allah SWT (Subhanahu Wa-Ta'ala), dalam surah Al-Ahzaab, 33:21, yang bermaksud:

\section{Sesungguhnya, bagi kamu pada diri Rasulullah itu model ikutan yang baik, iaitu bagi orang yang sentiasa mengharapkan (keredhaan) Allah dan (balasan baik) hari akhirat serta dia banyak menyebut dan mengingati Allah (dalam JPM Malaysia, 1983).}

Yusuf al-Qardhawi (1995), dan dipetik juga dalam J.M. Halstead (2007), membahagikan akhlak kepada 6 kategori, iaitu: akhlak terhadap diri sendiri, akhlak terhadap keluarga, akhlak terhadap masyarakat, akhlak terhadap binatang, akhlak terhadap alam sekitar, dan akhlak terhadap Allah (al-Qardhawi, 1995; dan Halstead, 2007). Manakala M.A. Darraz (1973); A. Azhar (2006); dan H. Azimi (2007) menghuraikan akhlak seorang Muslim terbahagi kepada akhlak peribadi, akhlak sosial, dan akhlak agama atau akhlak terhadap Allah (Darraz, 1973; Azhar, 2006; dan Azimi, 2007).

Sehubungan itu, konsep penghayatan akhlak Islam dalam kajian ini dapat disimpulkan sebagai tingkah-laku zahir pada seorang manusia, yang dilakukan secara berterusan (istiqamah) dalam konteks hubungannya dengan Allah SWT (Subhanahu Wa-Ta'ala), sesama manusia, dan hubungannya dengan alam berasaskan ajaran Al-Qur'an dan Sunnah Nabi Muhammad SAW (Azhar, 2006; dan Zakaria, Munawar \& Fatah, 2012).

Belia dan Permasalahan Akhlak. Belia adalah aset terpenting dan tunggak kemajuan sesebuah negara. Mereka adalah agen perubahan yang menjadi harapan nusa dan bangsa untuk meneruskan pembangunan dan menentukan nasib masyarakat serta masa depan negara. Maju atau mundur sesebuah masyarakat turut diukur daripada kualiti generasi mudanya pada hari ini.

Pada tahun 2005, seramai 11 juta, iaitu 42.5 peratus daripada 26.13 juta penduduk Malaysia terdiri daripada golongan belia. Pada tahun 2010, golongan belia meningkat kepada 11.26 juta, iaitu 40.6 peratus daripada populasi keseluruhan penduduk Malaysia (Shahrudin, Azman \& Mazlan, 2010). ${ }^{3}$ Memandangkan hampir separuh penduduk negara ini terdiri daripada golongan belia, permasalahan sosial dan akhlak juga banyak melibatkan golongan ini. Gejala seks bebas, pengguguran kandungan, kelahiran anak luar nikah, pembuangan bayi, dan pengambilan dadah dalam kalangan remaja dan belia hari ini bukan lagi menjadi suatu perkara asing dalam masyarakat.

Realitinya, pada masa kini mereka menerima perlakuan intim seperti berpeluk, bercium, dan hubungan seks antara pasangan kekasih sebagai suatu gaya hidup yang normal. Kajian yang dilakukan oleh Pertubuhan Kebajikan Darul Islam Selangor menunjukan daripada 30 siri

${ }^{3}$ Lihat juga "Jabatan Perangkaan Malaysia, 2011". Wujud dalam online di: http://www.statistics.gov.my/portal [diakses di Serdang, Malaysia: 13 Februari 2016]. 
Jadual 1:

Perbandingan Penagih yang Dikesan Mengikut Etnik dan Umur bagi Tahun 2009 dan 2010

\begin{tabular}{llcc}
\hline & Status $\backslash$ Tahun & $\mathbf{2 0 0 9}$ & $\mathbf{2 0 1 0}$ \\
\hline Penagih baru & & 7,123 & 17,238 \\
\hline Penagih berulang & & 8,613 & 6,404 \\
\hline Etnik & Melayu & 13,705 & 18,693 \\
& Cina & 951 & 2,279 \\
& India & 942 & 2,037 \\
& Pribumi Sabah & 56 & 456 \\
& Pribumi Sarawak & 23 & 29 \\
& Lain-lain & 148 \\
& Warga Asing & 55 & 0 \\
\hline Umur & $<13$ tahun & 4 & 3 \\
& $13-15$ tahun & 0 & 83 \\
& $16-18$ tahun & 47 & 2,055 \\
& $19-24$ tahun & 285 & 6,022 \\
& $25-29$ tahun & 3,020 & 4,993 \\
& $30-34$ tahun & 3,474 & 3,002 \\
& $35-39$ tahun & 3,219 & 2,720 \\
& $40-44$ tahun & 2,236 & 1,786 \\
$45-49$ tahun & 1,384 & 1,161 \\
& Tiada maklumat umur & 888 & 1,293 \\
\hline & Jumlah tangkapan keseluruhan & 906 & 524 \\
\hline
\end{tabular}

Sumber: Agensi ADK (2010).

seminar motivasi yang dikendalikan di Lembah Klang, 25-30 peratus pelajar sekolah menengah mengaku telah melakukan hubungan seks sejak memasuki sekolah menengah (dipetik dalam Fauzi \& Naim, 2012). Hakikatnya, pendedahan terhadap aktiviti seksual secara berterusan dan berleluasa daripada internet telah mempengaruhi remaja, sehingga terjebak dengan aktiviti seks bebas dan kehamilan luar nikah.

Laporan mengenai fenomena remaja Malaysia dan seks luar nikah turut didedahkan oleh Healthcare Malaysia Sdn Bhd (Sendirian Berhad), yang dibuat oleh Durex $2002 \mathrm{ke}$ atas 2,500 responden lelaki dan wanita yang berumur antara 18-30 tahun tanpa mengira bangsa. Berdasarkan soal selidik yang diedarkan, didapati remaja yang berumur dalam lingkungan 18 hingga 24 tahun paling kerap melakukan hubungan seks dan melahirkan anak luar nikah. Secara purata, remaja melakukan hubungan sebanyak 121 kali setahun, atau tiga kali seminggu, dan percintaan merupakan faktor utama responden melakukan seks luar nikah (dalam Farahwahida \& Norzila, 2011; dan Fauzi \& Naim, 2012).

Bagi kes pembuangan bayi pula, pada tahun 2007 hingga April 2010, sebanyak 312 kes pembuangan bayi direkodkan oleh JKM (Jabatan Kebajikan Masyarakat) dengan purata tiga bayi dibuang setiap dua minggu. Statistik kes pembuangan bayi yang dikeluarkan oleh PDRM (Polis Diraja Malaysia) pula menunjukan bahawa sebanyak 396 kes dicatatkan dari tahun 2005 hingga 2009, dengan sebahagian besar yang terlibat adalah belia berusia antara 18 hingga 25 tahun (dalam Idris \& Rahman, 2010). Apa yang lebih membimbangkan lagi ialah pembuangan bayi turut menular di institusi pengajian tinggi (Hashim et al., 2008).

Manakala dalam kes kelahiran anak luar nikah pula, statistik JPN (Jabatan Pendaftaran Negara) merekodkan bahawa pada tahun 
2000 hingga 2008, sebanyak 257,000 kelahiran bayi yang didaftarkan tidak mempunyai nama bapa. Ini bermakna secara purata 2,500 kes anak luar nikah direkodkan setiap bulan, atau hampir 84 kes pada setiap hari. Bagi tempoh lima tahun sebelumnya, iaitu antara tahun 1999 hingga 2003, suatu fakta yang menyedihkan apabila 44 peratus daripada 70,430 bayi yang didaftarkan tanpa mempunyai nama bapa adalah anak orang Islam (dalam Rohaniza Idris \& Rahman, 2010).

Penglibatan belia dalam kes penyalahgunaan dadah pula semakin meruncing dengan bertambahnya jumlah penagih dadah pada setiap tahun. Perbandingan penagih yang ditahan mengikut etnik dan umur pada tahun 2009 dan 2010 adalah seperti jadual 1 .

Berdasarkan jadual 1, seramai 23,642 orang penagih telah dikesan pada tahun 2010 dan menunjukan peningkatan sebanyak 50.24 peratus berbanding tahun 2009 , iaitu seramai 15,736 orang. Peningkatan penagih baru berlaku sebanyak 142 peratus, iaitu seramai 17,238 orang berbanding 7,123 orang pada tahun 2009. Ini bermakna secara purata pada tahun 2010, seramai 1,437 penagih baru dikesan pada setiap bulan, 48 orang pada setiap hari, dan 2 orang pada setiap jam.

Daripada segi profil penagih mengikut etnik, bangsa Melayu beragama Islam merupakan kumpulan penagih teramai yang dikesan sepanjang tahun 2010, iaitu seramai 18,693 orang (79.07 peratus). Daripada segi umur pula, jumlah belia paling ramai terlibat dengan jumlah keseluruhan seramai 16,737 orang ( 72.40 peratus). Fakta menggerunkan apabila berlakunya peningkatan jumlah belia terlibat yang berusia 19 hingga 24 tahun dan 25 hingga 29 tahun, iaitu sebanyak 99.40 peratus dan 43.72 peratus. Peningkatan penagih belia berumur antara 19 hingga 24 tahun sebanyak 99.4 peratus, iaitu dari 3,020 pada tahun 2009 kepada 6,022 orang tahun 2010.

Laporan dan statistik yang telah dibincangkan memaparkan permasalahan akhlak belia negara ini yang membimbangkan dan perlu diberi perhatian serius oleh semua pihak (Aidid, 2002). Ini kerana belia yang sepatutnya memiliki jati diri yang kental dan semangat yang tinggi telah keliru dan hilang keyakinan, longgar pegangan agama, terhakisnya budaya warisan, dan muncul pula budaya baharu yang bertentangan dengan nilai ke-Timur-an dan prinsip Islam.

\section{Permasalahan Akhlak Belia di} Institusi Pengajian Tinggi. Pada tahun 2009 , terdapat 470,772 orang pelajar prasiswazah di semua IPTA (Intitusi Pengajian Tinggi Awam) di Malaysia (KPT Malaysia, 2010). Mereka merupakan golongan terpelajar dan berpendidikan tinggi, yang bakal menyumbang kepada pembangunan modal insan utama negara dan seterusnya mengambil alih tampuk kepimpinan negara.

Walau bagaimanapun, terdapat penemuan tingkah-laku golongan ini yang membimbangkan. Kajian oleh R.V. Khaidzir \& H.H. Hanina (2010) dalam kalangan belia IPTA sangat mengejutkan, apabila mendapati seramai 793 orang atau sekitar 79.3 peratus daripada 1,000 orang responden berpotensi dan mempunyai kecenderungan untuk terlibat dengan aktiviti penyalahgunaan bahan, seperti dadah dan alkohol (Khaidzir \& Hanina, 2010). Begitu juga dengan laporan daripada Agensi ADK (Anti Dadah Kebangsaan), pada tahun 2010, yang mendapati seramai 362 penagih dikesan mempunyai kelayakan akademik peringkat diploma dan ijazah pada tahun 2010, berbanding dengan tahun 2009 iaitu seramai 79 orang (Agensi ADK, 2010).

Kepincangan akhlak belia di peringkat pengajian tinggi juga dilaporkan dalam media, terutama media cetak. Kesalahan khalwat, bersekedudukan, dan menjual maruah adalah sebahagian daripada salah laku yang pernah dilaporkan oleh pelajar IPT (Institusi Pengajian Tinggi). Sebagai contoh, akhbar Berita Harian, terbitan 22 Mei 2006, melaporkan bahawa khalwat dan berdua- 
duaan adalah kes paling tinggi dikenakan tindakan tata-tertib membabitkan pelajar IPT mengikut AUKU (Akta Universiti dan Kolej Universiti) Tahun 1971. Statistik menunjukan sejak 1971 sehingga awal tahun 2006, sebanyak 3,818 kegiatan berkenaan dikenakan tindakan tata-tertib oleh pihak universiti (dalam Melati \& Zaharah, 2006). Ini bermakna purata 100 kes salah laku pelajar IPT dikenakan tindakan bagi setiap tahun.

Walaupun jumlah belia IPTA yang terlibat bukanlah suatu angka yang sangat besar berbanding dengan populasi mereka, namun perkara ini tidak sewajarnya berlaku memandangkan harapan negara terhadap golongan ini begitu tinggi. Mereka adalah kumpulan utama yang akan menggerakan jentera pembangunan negara dan masyarakat pada masa depan. Mereka juga adalah modal insan yang diharapkan untuk menentukan kualiti hidup masyarakat dan negara (Hassan, 1999).

Persoalan yang timbul di sini adalah apakah tahap penghayatan akhlak belia? Apakah institusi keluarga gagal memainkan peranan dalam pembentukan akhlak belia? Sedangkan Islam amat menekankan tingkah-laku yang mulia dengan menjadikan Rasulullah SAW (Salallahu Alaihi Wassalam) sebagai model ikutan, sehinggakan $\mathrm{Al}$ Qur'an sendiri telah memujinya dalam surah Al-Qalam, 68:4, yang bermaksud:

\section{Sesungguhnya engkau (Muhammad) mempunyai akhlak yang sangat mulia (dalam JPM Malaysia, 1983).}

Sehubungan itu, apabila membincangkan permasalahan akhlak belia, isu ini tidak pernah selesai. Pelbagai faktor perlu dilihat seperti peranan ibu bapa, rakan sebaya, dan faktor-faktor lain. Hasil daripada isu dan persoalan yang timbul, maka usaha untuk mengkaji bidang ini dengan lebih mendalam perlulah dilakukan untuk mencari penjelasan tentang akhlak belia di negara ini.

\section{PEMBENTUKAN \\ TINGKAH-LAKU BELIA}

Pembangunan belia yang seimbang adalah proses pendidikan sepanjang hayat, bagi seseorang manusia, merangkumi pendidikan formal di sekolah dan pendidikan tidak formal di luar alam persekolahan. Namun, hakikatnya ramai yang tidak menyedari bahawa proses pendidikan dalam membangunkan seorang belia bermula dalam institusi keluarga, iaitu secara tidak formal, sejak lahirnya seorang anak. Ibu bapa berperanan sebagai guru dan model dalam mendidik akhlak anak-anak di rumah; dan menerusi alam persekolahan pula, kanakkanak dan remaja dibentuk pribadinya menerusi ilmu pendidikan yang bersifat formal. Ini kerana dalam era globalisasi, cabaran kepada kehidupan belia sangat getir, khususnya melibatkan nilai-nilai akidah, spiritual, dan budaya.

Teori-teori Barat berpendapat bahawa proses pendidikan belia bermula sejak kanak-kanak, menerusi hubungannya dengan persekitaran melibatkan individu yang signifikan, seperti ibu bapa dan rakan sebaya (cf Bandura, 1977; Bronfenbrenner, 1979; dan Bowlby, 1989). Menurut A. Bandura (1977), tingkah-laku manusia adalah hasil interaksi individu dengan persekitaran. Kanak-kanak dan remaja bertingkahlaku kesan pemerhatian dan peniruan dengan orang-orang yang signifikan dalam kehidupan mereka, khususnya ibu bapa (Bandura, 1977).

Berdasarkan teori ini, ibu bapa adalah orang yang paling rapat dan berpengaruh dalam pembentukan tingkah-laku seorang anak. Sehubungan itu, proses pembelajaran yang dilalui oleh belia dalam persekitaran yang positif sejak bayi hingga dewasa akan menghasilkan belia yang positif.

Teori Psikososial oleh E.H. Erikson (1959) pula menjelaskan bahawa proses sosialisasi seorang manusia melalui lapan tahap perkembangan yang berlaku secara berterusan sepanjang hayat manusia sejak 
lahir hingga meninggal dunia. Menurut teori ini, pada setiap tahap terdapat konflik yang perlu dilalui oleh manusia. Peringkat remaja dan belia adalah peringkat yang getir, kerana pada tahap inilah proses pembentukan identiti berlaku. Persekitaran yang positif melibatkan ibu bapa, guru, dan rakan sebaya memberi pengaruh kuat kepada pembentukan identiti belia (Erikson, 1959).

Manakala U. Bronfenbrenner (1979), dalam Teori Ekologi Manusia, pula menjelaskan bahawa tingkah-laku belia dipengaruhi oleh unsur yang datang daripada luar persekitaran terhampir, yang dinamakan sistem mikro, meso, ekosistem, makro, dan krono ( $c f$ Bronfenbrenner, 1979; dan Rozumah, 2009). Sistem mikro adalah sistem yang paling hampir. Ia lazimnya mempengaruhi tingkah-laku seorang belia menerusi konteks sistem keluarga, iaitu ibu bapa; dan diikuti oleh konteks luar keluarga, iaitu rakan sebaya, jiran tetangga, dan sekolah (Bronfenbrenner, 1979; dan Rozumah, 2009).

Menurut pandangan Islam pula, tingkahlaku manusia boleh dibentuk dan diasuh menjadi akhlak yang mulia menerusi kaedah mujahadah (perjuangan) dan riyadah (latihan). Kaedah ini merujuk kepada kaedah pendidikan dengan cara berusaha bersungguh-sungguh melakukan kebaikan, sehingga menjadi kebiasaan dan sifat semulajadi (Nasir, 2010). Kaedah ini juga berkesan untuk membebaskan diri daripada akhlak yang hina (mazmumah) dan menukarkannya menjadi akhlak yang mulia (mahmudah); dan ini dijelaskan oleh M. AlGhazali (1988) sebagai tazkiyah al-nafs atau pembersihan jiwa (cf Al-Ghazali, 1988; dan Zakaria, 2001). Bersahabat dengan sahabat yang baik dan soleh merupakan salah satu kaedah pendidikan yang ditekankan dalam proses pembersihan jiwa manusia (Al-Ghazali, 1988; Zakaria, 2001; dan Nasir, 2010).

\section{Faktor-faktor Mempengaruhi} Keruntuhan Akhlak Belia. Secara konseptualnya, keruntuhan akhlak belia dapat digambarkan sebagai kehilangan nilai-nilai kemanusiaan dalam diri seorang manusia (Ismail, 2005). Manakala Muhammad Iqbal (1987), dan dipetik pula dalam A. Azhar (2006), menggambarkan gejala kemerosotan akhlak sebagai: (1) gejala kehilangan perimbangan potensi diri manusia; (2) timbul jurang yang luas di antara aspek lahir dan batin, akal dan hati, serta ilmu dan akidah; (3) hilang jati diri, lemah keyakinan, dan tiada harapan; (4) tercabut keyakinan kepada agama dan Allah; (5) akal yang cetek dan hati yang keras daripada menerima kebenaran agama; (6) agama, siasah, akal, dan hati hanya melingkar di sekitar kebendaan; serta (7) hidup diselubungi kebekuan dan kepincangan (Iqbal, 1987; dan Azhar, 2006). Ini menggambarkan secara jelas hakikat dan faktor keruntuhan akhlak manusia.

Kajian-kajian mengenai punca gejala sosial dan keruntuhan akhlak belia dikaitkan dengan faktor-faktor: kegagalan ibu bapa untuk mendidik anak-anak (Ozman, 2000; Ismail, 2005; dan Hashim et al., 2008); pengaruh rakan sebaya (Ozman, 2000; Ismail, 2005; dan Hashim et al., 2008); pengaruh media massa (Ismail, 2005; Halim \& Zarin, 2009; dan Munawar \& Shahizan, 2011); pegangan akidah yang tidak kukuh (Ismail, 2005; dan Munawar, 2009); serta kelemahan sistem pendidikan negara (Ozman, 2000).

Kajian-kajian lepas mengenai penghayatan akhlak Islam dalam bentuk lapangan telah dilakukan oleh A. Azhar (2006) ke atas 935 orang remaja sekolah menengah di Sarawak, Malaysia, dan mendapati tahap penghayatan akhlak Islam dalam kalangan responden berada pada tahap sederhana tinggi (Azhar, 2006). Manakala kajian oleh I. Ahmad Munawar (2009) ke atas remaja sekolah menengah di Semenanjung Malaysia pula mendapati tahap penghayatan akhlak Islam berada pada tahap tinggi (Munawar, 2009). Dapatan kajian oleh T. Ab Halim \& I. Zarin (2009) ke atas 398 remaja sekolah menengah di Sabak Bernam, Selangor, Malaysia, 
mendapati tahap penghayatan akhlak Islam responden hanya berada pada tahap sederhana sahaja (Halim \& Zarin, 2009).

Seterusnya, kajian oleh M. Dearana (2010) ke atas 300 orang remaja sekolah menengah di Sarawak, Malaysia, mendapati tahap penghayatan akhlak Islam remaja berada pada tahap sederhana tinggi (Dearana, 2010). Hasil dapatan daripada M. Dearana (2010) ini adalah sama dengan dapatan A. Azhar (2006).

Kajian penghayatan akhlak Islam melibatkan belia di institusi pengajian tinggi hanya dilakukan oleh W.H. Wan Norina et al. (2013), yang melibatkan 397 orang belia peringkat diploma politeknik di Malaysia. Kajian menumpukan kepada hubungan media massa ke atas penghayatan akhlak Islam. Hasil dapatan kajian menunjukan tahap penghayatan akhlak Islam dalam kalangan belia politeknik berada pada tahap tinggi, manakala media massa mempunyai hubungan yang signifikan ke atas akhlak belia (Norina et al., 2013).

\section{Pendidikan Keagamaan dalam Institusi}

Keluarga. Pembangunan sahsiah belia bermula dalam bentuk pendidikan tidak formal, iaitu berlaku di rumah dengan persekitaran keluarga dan keibubapaan yang harmoni, sekaligus membolehkan mereka memiliki akhlak yang mulia. Ibu bapa memainkan peranan penting dalam perkembangan belia dan berperanan mencorakan masa depan mereka (Zulkifli et al., 2011). Suasana keluarga yang tidak harmoni dan tanpa kasih sayang daripada ibu bapa akan mendorong remaja mencari kebahagiaan dan keseronokan di luar rumah bersama rakan sebaya (Hamachek, 1995; dan Jamali et al., 2010); manakala didikan awal yang sempurna boleh menjamin kejayaan anak-anak di masa hadapan dan tidak terjebak dalam perbuatan-perbuatan yang negatif (Halimah \& Kamariah, 1993; dan Khaidzir \& Hanina, 2010).

Dalam menangani keruntuhan akhlak yang berlaku pada hari ini, pendidikan keagamaan, sama ada secara formal di sekolah mahupun tidak formal bersama ibu bapa serta masyarakat, perlu diberi penekanan kepada belia sebagai jalan penyelesaian jangka panjang (Razaleigh \& Tarmizi, 2010). Menurut Elizabeth B. Hurlock (1974), dan dipetik juga dalam M. Mohd Ismail (1999), ibu bapa merupakan agen sosialisasi terpenting dalam pembentukan personaliti anak-anak (Hurlock, 1974; dan Ismail, 1999). Ibu bapa merupakan kumpulan sosial pertama yang dikenali oleh kanak-kanak untuk berinteraksi (Mahmood, 2008).

Kanak-kanak menghabiskan masa yang lama bersama ibu bapa berbanding kumpulan sosial yang lain. Tempoh kritikal dalam pembentukan manusia, terutama sebelum remaja atau baligh, ialah semasa bersama keluarga. Selepas memasuki alam sekolah menengah, jika remaja belum membentuk identiti yang sempurna, mereka akan mengalami krisis identiti (Erikson, 1959; dan Erikson, 1968). Dalam pencarian identiti diri, remaja akan mudah terpengaruh dengan rakan sebaya, persekitaran, dan budaya semasa. Sekiranya ibu bapa gagal membentuk remaja yang berpegang kepada agama, mereka akan berhadapan dengan cabaran yang besar untuk memulihkan semula keadaan remaja (Ismail, 1999; dan Azimi, 2007).

Pendidikan secara tidak formal, menerusi institusi keluarga, dengan menekankan pengajaran agama dan nilai-nilai murni selaras dengan norma masyarakat amat penting bagi memastikan kerohanian yang mantap dalam diri anak-anak dibentuk (Yaacob, 2007). Dalam Islam, peranan ibu bapa dalam mendidik anak-anak sangat besar, yang merangkumi pendidikan akidah, ibadah, dan akhlak (Mustafa, 1997; dan Nashih, 2000). Ibu bapa bertanggung jawab menentukan masa depan anak-anak mereka, seperti dijelaskan dalam Hadist Rasulullah SAW (Salallahu Alaihi Wassalam), seperti dipetik dalam Riwayat Bukhari \& Muslim, yang bermaksud: 
Setiap anak dilahirkan di atas fitrah, maka kedua ibu bapanya menentukan, sama ada menjadi Yahudi, Nasrani, atau Majusi (dalam Hasnan, 2008).

Corak pendidikan anak-anak sewaktu kecil sehingga remaja dijadikan kayu pengukur kepada pembentukan peribadi anak-anak apabila dewasa. Individu yang lahir dan membesar dalam keluarga, yang mementingkan ilmu pengetahuan dan menekankan akhlak yang mulia, akan menghasilkan individu yang mampu memberi impak berguna kepada agama, masyarakat, dan negara. Ini dibuktikan apabila kajian oleh W.S. Wan Noor Shazalina (2009) di Kelantan, Malaysia, yang menunjukkan bahawa pendidikan agama secara tidak formal, yang dilalui bersama ibu bapa, mempunyai hubungan yang signifikan dengan moral remaja (Shazalina, 2009).

Menurut U. Abdullah Nashih (1998), tanggung jawab pendidikan anak-anak memerlukan ibu bapa untuk memainkan peranan yang aktif dan merangkumi tujuh aspek, iaitu: pendidikan keimanan, akhlak, jasmani, intelektual, psikologi, kemasyarakatan, dan pendidikan seks (Nashih, 1998). Metodologi pendidikan anakanak yang berkesan pula perlu dilakukan oleh pendidik, sama ada ibu bapa mahupun guru, yang merangkumi lima perkara, iaitu: melalui contoh teladan, kebiasaan atau adat, pengajaran, pemerhatian, dan melalui hukuman atau denda (Nashih, 2000).

Pendidikan menerusi contoh teladan yang baik oleh ibu bapa, samaada dalam percakapan atau perbuatan, adalah sangat berkesan kerana ibu bapa adalah role model kepada anak-anak (Mahmood, 2008).

Penekanan kepada aspek disiplin juga sangat penting dilakukan oleh ibu bapa di rumah, dan tidak sewajarnya diserahkan sepenuhya kepada pihak sekolah. Ini kerana hakikat pembentukan akhlak anak-anak bermula di rumah, iaitu oleh ibu bapa yang menekankan aspek disiplin dalam keluarga (Asmak, 2006; dan Munawar \& Noranizah, 2012).

Menurut Mohd Ali Hassan (2004), dan dipetik juga dalam A. Azhar (2006), ibu bapa perlu memainkan peranan dalam pendidikan anak-anak dengan cara menyediakan pembelajaran yang diperlukan, membantu anak membina matlamat hidup, memberikan motivasi, memberi galakan dalam pelajaran, mengikuti perkembangan kemajuan anak, membantu menyelesaikan masalah, memperkaya pengalaman anak dengan persekitaran dan sosial, memberi contoh teladan, serta menyemai budaya belajar ke dalam jiwa anak-anak seawal mungkin (Hassan, 2004; dan Azhar, 2006).

Namun, pada masa kini kekeliruan sering dilakukan oleh ibu bapa dalam mendidik anak-anak. Ibu bapa gagal membentuk persekitaran yang cintakan agama. Contohnya, dalam mendidik anak-anak supaya cintakan ibadah solat, Rasulullah SAW (Salallahu Alaihi Wassalam) sendiri membiarkan cucunya, Husain, berada di sisi Baginda sewaktu solat (dalam Hasnan, 2008). Hasilnya, berlaku proses peniruan tingkah-laku oleh kanak-kanak sehingga membentuk kelaziman dan membuahkan perasaan cintakan agama. Sebaliknya, ibu bapa kini sering mengusir anak-anak yang masih kecil supaya berada jauh daripada mereka ketika solat, kerana tidak mahu menjejaskan tumpuan mereka untuk solat.

Jelaslah bahawa proses pembelajaran sepanjang hayat bermula dalam institusi keluarga, khususnya melibatkan ibu bapa. Ibu bapa berperanan penting dalam pembentukan peribadi dan akhlak anak-anak. Mereka adalah model dan contoh ikutan dalam pembentukan tingkah-laku remaja dan belia (Mahmood, 2008). Proses pendidikan yang dilalui di rumah bersama ibu bapa sangat penting sebelum mereka bergaul dengan rakan sebaya dan ahli masyarakat yang lain. Hubungan yang baik dengan ibu bapa menjadi asas kepada anak-anak supaya tidak mudah terpengaruh dengan rakan sebaya yang membawa unsur negatif (Jamali et al., 
2010). Anak-anak ibarat kain putih yang suci dan bersih, maka ibu bapa perlu memainkan peranan untuk mencorakan kehidupan anakanak mereka.

\section{Hubungan Ibu Bapa dengan Tingkah-}

Laku Belia. Ibu bapa mempunyai hubungan yang erat dalam pembentukan tingkah-laku belia. Kajian oleh M.D.S. Ainsworth et al. (1978) menunjukan bahawa ibu bapa yang tidak sensitif terhadap keperluan seorang anak, bersikap tidak mesra, penyeliaan yang tidak baik, amalan penjagaan yang tidak konsisten, dan cara asuhan serta didikan yang tidak sempurna memberi kesan ke atas tingkah-laku remaja dan belia (Ainsworth et al., 1978). Mereka (remaja dan belia) didapati mudah terlibat dalam kes-kes, seperti: delinkuen (Bee \& Boyd, 2002; Magoon \& Ingersoll, 2006; dan Svensson et al., 2012); permasalahan sosial seperti berpelesiran, merempit, dan merokok (Bandura \& Walters, 1963; dan Ezhar et al., 2008); lari dari rumah (Ozman, 2000); serta mudah mengalami kemurungan dalam kehidupan (Rohana, 2004; dan Asnarulhadi, 2009).

Sebaliknya, hubungan ibu bapa yang positif dengan anak-anak menghasilkan tingkah-laku yang baik ke atas belia. Kajian menunjukan hubungan yang selamat, berkualiti, dan harmoni antara ibu bapa dan anak mempengaruhi: perkembangan estim kendiri anak yang positif (Armsden \& Greenberg, 1987); memiliki kemahiran sosialisasi yang baik (Kenny \& Rice, 1995); meningkatkan keyakinan diri dan eksplorasi diri (Baumrind, 1991; Isa, 2011; dan Zakaria, Munawar \& Noranizah, 2012); meningkatkan pencapaian dalam akademik (Zulkifli et al., 2011); serta menjadi contoh teladan dalam penghayatan akhlak Islam belia (Azhar, 2006; Ahmad Munawar, 2009; dan Dearana, 2010).

Kajian oleh H.A. Asmak (2006) ke atas remaja di Petaling Jaya dan Shah Alam, Malaysia, mendapati bahawa usaha menangani permasalahan akhlak belia adalah dengan perhatian yang diberikan oleh ibu bapa, 29.8 peratus; diikuti oleh nasihat dan bimbingan, 23.4 peratus; program motivasi, 26 peratus; program pemantapan iman, 7.8 peratus; penguatkuasaan, 6.4 peratus; dan lain-lain, 6.4 peratus (Asmak, 2006). Begitu juga dengan kajian oleh M. Dearana (2010) ke atas remaja di sekolah menengah di Miri, Sarawak, Malaysia, mendapati bahawa faktor ibu bapa sebagai contoh teladan dalam penghayatan akhlak Islam menunjukan hubungan yang signifikan dengan akhlak remaja, iaitu $\mathrm{r}=0.336$; mengatasi faktor guru, iaitu $r=0.308$ (Dearana, 2010).

Teori pertautan telah diperkenalkan oleh J. Bowlby (1989), dan telah digunakan oleh G.C. Armsden \& M.T. Greenberg (1987), untuk membina IPPA (Inventory of Parent and Peer Attachment), yang banyak digunakan dalam kajian untuk menentukan hubungan ibu bapa dan rakan sebaya dengan tingkah-laku remaja dan belia ( $c f$ Armsden \& Greenberg, 1987; Bowlby, 1989; Armsden et al., 1990; Paterson, Field \& Pryor, 1994; Rohana, 2004; dan Isa, 2011).

Pertautan mengandungi tiga faktor utama, iaitu kepercayaan, komunikasi, dan rasa diterima atau rasa disingkirkan. Ketiga-tiga faktor ini menyumbang kepada pembentukan diri anak-anak, sama ada ke arah kebaikan atau sebaliknya (Armsden \& Greenberg, 1987; dan Bowlby, 1989).

\section{KESIMPULAN}

Belia adalah aset terpenting dan bakal mewarisi kepimpinan masa depan negara. Golongan ini adalah kumpulan terbesar penduduk di negara Malaysia ini; dan majoritinya adalah terdiri daripada belia Muslim. Pembentukan akhlak yang terpuji dapat menjamin pembangunan belia yang positif. Aspek pendidikan keagamaan oleh ibu bapa, pertautan ibu bapa, dan pertautan rakan sebaya perlu diberi penekanan dalam pembangunan akhlak belia Muslim. Ini kerana dengan berlakunya penghayatan akhlak Islam dalam diri setiap belia akan membentuk belia menjadi insan kamil yang dihormati dan disanjung tinggi 
oleh masyarakat. Generasi belia ini akan mencorakan masa depan negara dan membentuk kejayaan sebuah tamadun bangsa.

Proses membentuk belia yang berakhlak mulia memerlukan kesepaduan antara pendidikan secara formal dan tidak formal. Proses pembelajaran secara tidak formal yang dilalui bersama masyarakat, khususnya ibu bapa dan rakan sebaya, tidak boleh diambil mudah, malah perlu diberi perhatian serius kerana tempoh masa yang dihabiskan bersama ibu bapa dan rakan sebaya adalah lebih panjang berbanding masa yang diluangkan dalam pendidikan formal. Pembentukan akhlak belia untuk menjadi insan kamil yang cemerlang dan seimbang dari segi intelek dan spiritual adalah proses pendidikan sepanjang hayat dan perlu diberi penekanan selaras dengan pembangunan dan kemajuan negara.

Belia yang positif adalah belia yang memiliki akhlak yang terpuji. Penghayatan akhlak Islam perlu bermula daripada diri belia dan berkembang membentuk masyarakat yang berakhlak mulia, dan seterusnya membentuk tamadun bangsa yang gemilang, seperti yang diasaskan oleh Rasulullah SAW (Salallahu Alaihi Wassalam ${ }^{4}{ }^{4}$

\section{Referensi}

Abdullah, B. (2006). "Membina Tamadun Menjulang Martabat Negara". Kertas Ucapan Perdana Menteri YAB Dato' Seri Abdullah Ahmad Badawi semasa membentangkan Usul mengenai RMK-9, 2006-2010, di Dewan Rakyat Malaysia, pada 31 Mac. Wujud dalam online pula di: http://www. ipislam.edu.my/ index.php/artikel/read/400/ membina-tamadun-menjulang-martabat-negara

\footnotetext{
${ }^{4}$ Kenyataan: Dengan ini, kami membuat kenyataan bahawa artikel ini adalah merupakan dapatan pemikiran dan penyelidikan kami berdua. Ianya bukan dapatan daripada amalan plagiarism, sebab sumber-sumber yang kami petik jelas wujud dalam senarai Rujukan atau Referensi. Kertas ini juga belum dinilai dan belum diterbit oleh mana-mana jurnal akademik, samada di Malaysia mahupun di luar negara.
}

[diakses di Serdang, Malaysia: 17 Mei 2016]. Agensi ADK [Anti Dadah Kebangsaan]. (2010). "Laporan Dadah Disember 2010". Wujud dalam online di: http://www.adk.gov.my/web/guest/ dadah-2010 [diakses di Serdang, Malaysia: 17 Mei 2016].

Aidid, Syed Arabi. (2002). Kaedah Penyelidikan Komunikasi dan Sains Sosial. Kuala Lumpur: Dewan Bahasa dan Pustaka.

Ainsworth, M.D.S. et al. (1978). Patterns of Attachment: A Psychological Study of the Strange Situation. New Jersey: Lawrence Erlbaum Associates.

Al-Ghazali, M. (1988). Ihya'Ulumuddin. Singapura: Pustaka Nasional.

al-Qardhawi, Yusuf. (1995). Al-Hayat al-Rabbaniah wa al-'Ilm [Kehidupan Rabbani dan Ilmu]. Kaherah, Mesir: Maktabah Wahbah.

Argue, A., D.R. Johnson \& L.K. White. (1999). “Age and Religiosity: Evidence from a Three-Wave Panel Analysis" dalam Journal for the Scientific Study of Religion, 38(3), ms.423-435.

Armsden, G.C. \& M.T. Greenberg. (1987). "The Inventory of Parent and Peer Attachment: Individual Differences and Their Relationship to Psychological Well-Being in Adolescence" dalam Journal of Youth and Adolescence, 16(5), ms.427-454.

Armsden, G.C. et al. (1990). "Parent and Peer Attachment in Early Adolescent Depression" dalam Journal of Abnormal Child Psychology, 18(6), ms.683-697.

Asmak, H.A. (2006). "Salah Laku Sosial Remaja Masa Kini: Cabaran dan Penyelesaiannya" dalam A.R. Abd Rahim, H. Sufean \& T. Jamaludin [eds]. Institusi Keluarga Menghadapi Cabaran Alaf Baru. Kuala Lumpur: Utusan Publication \& Distributors Sdn Bhd.

Asnarulhadi, A.S. (2009). "Kelompangan Dasar Belia: Menyangga Potensi Belia Menerusi Pendekatan Transformasi Konflik" dalam Malaysian Journal of Youth Studies, 1, ms.1-22.

Azhar, A. (2006). "Strategi Pembelajaran Kendiri Pendidikan Islam dan Penghayatan Akhlak Pelajar Sekolah Menengah di Sarawak". Tesis Ph.D. Tidak Diterbitkan. Bangi, Selangor: UKM [Universiti Kebangsaan Malaysia].

Azimi, H. (2007). "Situation of Girls and Young Women in Malaysia". Wujud dalam online di: http://www.ippbm.gov.my/v3/index.html [diakses di Serdang, Malaysia: 2 Ogos 2015].

Azizan, B. (1991). Belia dan Masyarakat. Pulau Pinang: Majlis Belia Pulau Pinang.

Bandura, A. (1977). Social Learning Theory. New Jersey: Prentice-Hall.

Bandura, A. \& R.H. Walters. (1963). Social Learning 
and Personality Development. USA [United States of America]: Hot, Rinehart and Winston, Inc.

Baumrind, D. (1991). "The Influence of Parenting Style on Adolescent Competence and Substance Use" dalam The Journal of Early Adolescence, 11(1), ms.56-95.

Bee, H. \& D. Boyd. (2002). Lifespan Development. Boston: Ally \& Bacon, 3rd edition.

Benson, P.L. et al. (1998). "Beyond the 'Village Rhetoric': Creating Healthy Communities for Children and Adolescents" dalam Applied Development Science, 2(3), ms.138-159.

Bowlby, J. (1989). Attachment and Loss, Volume 1: Attachment. New York: Basic Book.

Bronfenbrenner, U. (1979). The Ecology of Human Development: Experiments by Nature and Design. Cambridge, MA: Harvard University Press.

"Commonwealth Youth Programme Strategic Plan, 2008 - 2012". Wujud dalam online di: $\underline{\mathrm{http}: / /}$ www.thecommonwealth.org/files/229253/ FileName/CommonwealthYouthProgramme StrategicPlan2008-2012.pdf [diakses di Serdang, Malaysia: 14 Februari 2016].

Darraz, M.A. (1973). Dustur al-Akhlak fi Al-Quran. Beirut: Muassasah al-Risalah.

DBP [Dewan Bahasa dan Pustaka] Malaysia. (1998). Kamus Dewan. Kuala Lumpur: Dewan Bahasa dan Pustaka.

Dearana, M. (2010). “Hubungan Ibadah Solat Fardu dan Penghayatan Akhlak Pelajar: Kajian di Bahagian Miri, Sarawak". Tesis Sarjana Tidak Diterbitkan. Bangi, Selangor: UKM [Universiti Kebangsaan Malaysia].

Erikson, E.H. (1959). Psychological Issues: Identity and the Life Cycle. New York: International Universities Press.

Erikson, E.H. (1963). Childhood and Society. New York: Norton, 2nd edition.

Erikson, E.H. (1968). Identity: Youth and Crisis. London: Faber and Faber.

Ezhar, T. et al. (2008). "Penglibatan Remaja Bandar Berpendapatan Rendah dalam Masalah Sosial" dalam Jurnal Pembangunan Belia Malaysia, 1, ms.165-182.

Faizah, Y. (2007). "Youth Employment and Employbility in Malaysia". Paper for Round Table Discussion on Youth for Nation Building. Wujud dalam online pula di: http://www.ippbm.gov.my/v2/index. php?option $=$ com rubberdoc $\&$ view $=$ category $\& i d=$ $\underline{32 \& \text { Itemid }=25 \& \text { lang }=\text { bm\&limitstart }=20}$ [diakses di Serdang, Malaysia: 16 Mac 2016].

Farahwahida, M.Y. \& S. Norzila. (2011). "Persepsi Pelajar Institut Pengajian Tinggi Awam terhadap Amalan Seks Bebas" dalam Journal of Education Psychology \& Counseling, 1, ms.94-114.
Fauzi, H. Mohd \& C.N. Mohd Khairul Naim. (2012).

"Tinjauan Kepentingan Pembangunan Modal Insan di Malaysia (Review on the Importance of Human Capital Development in Malaysia)" dalam Jurnal Al-Tamaddun, Bil.7(1), ms.75-89.

Fazilah, I. (2009). "Personaliti, Belia, dan Perpaduan Etnik dalam Personaliti dan Pembangunan Insan" dalam M. Khairul Anwar et al. [eds]. Personaliti dan Pembangunan Insan. Bangi: Pusat Pengajian Umum UKM [Universiti Kebangsaan Malaysia], ms.163-186.

Hafiz, M.T. Abdul, S. Zakaria \& I. Ahmad Munawar. (2012). "Memperkasa Jati Diri Melayu-Muslim Menerusi Pendidikan Islam dalam Pengajaran Akhlak" dalam Jurnal Hadhari, Edisi Khas, ms.23-35.

Halim, T. Ab \& I. Zarin. (2009). "Hubungan antara Pegangan Nilai Moral dengan Media Massa: Tinjauan ke atas Remaja Melayu Luar Bandar" dalam SARI: Jurnal Alam dan Tamadun Melayu, 27, ms.199-212.

Halimah, A.R. \& I. Kamariah. (1993). Pengurusan dan Pengelolaan Pusat Pra-Sekolah. Kuala Lumpur: Fajar Bakti.

Halstead, J.M. (2007). "Islamic Values: A Distinctive Framework for Moral Education?" dalam Journal of Moral Education, 36(3), ms.283-296.

Hamachek, D. (1995). Psychology in Teaching, Learning, and Growth. Boston: Allyn and Bacon.

Hamid, A. Ab. (2011). Detik-detik Constantinople dan Ibrah buat Eropah. Kuala Lumpur: Mazni Irfan Publication.

Hashim, B. et al. (2008). "Keruntuhan Akhlak dan Gejala Sosial dalam Keluarga: Isu dan Cabaran”. Kertas kerja dibentang dalam Seminar Kaunseling Keluarga di Johor Bahru, Malaysia, pada tarikh 30 Ogos.

Hasnan, K. (2008). Pendidikan Remaja Muslim. Putrajaya: JAKIM [Jabatan Kebajikan Islam Malaysia].

Hassan, Mohd Ali. (2004). "Masalah Disiplin dan Jenayah di Kalangan Pelajar-pelajar Sekolah di Malaysia". Nota Forum dalam Seminar Kebangsaan Pencegahan Jenayah Faktor Persekitaran Sosial dan Hubungannya Dengan Pembentukan Jati Diri Menurut Perspektif Islam, Anjuran bersama IKIM [Institut Kefahaman Islam Malaysia] dan JAKIM [Jabatan Kebajikan Islam Malaysia], pada tarikh 10-11 Februari.

Hassan, O. Abu. (1999). "Pengurusan Pelajar di Institusi Pengajian Tinggi: Suatu Huraian Kritis" dalam Jurnal Personalia Pelajar, 5, ms.9-18.

Hurlock, Elizabeth B. (1974). Personality Development. New York: McGraw-Hill.

Idris, Rohaniza \& Umi Nadirah Abdul Rahman. (2010). "Empat Lagi Kes Buang Bayi" 
dalam akhbar Berita Harian. Kuala Lumpur, Malaysua: 14 Ogos. Wujud dalam online juga di: http://www.bharian.com.my/bharian/articles/ Empatlagikesbuangbayi/Article [diakses di Serdang, Malaysia: 17 Mei 2016].

Ingersoll, G.M. (1989). Adolescence. New Jersey: Prentice Hall, 2nd edition.

Iqbal, Muhammad. (1987). Javed Namah. Jakarta, Indonesia: Pustaka Panji Mas, terjemahan oleh Muhammad Sadikin.

Isa, A. Mohamad. (2011). "Pertautan Ibu Bapa dan Rakan Sebaya dalam Kalangan Pelajar Universiti serta Hubungannya dengan Yakin Diri dan Eksplorasi Diri". Tesis Ph.D. Tidak Diterbitkan. Bangi, Selangor: UKM [Universiti Kebangsaan Malaysia].

Ismail, M. Mohd. (1999). "Belia sebagai Insan Cemerlang dari Perspektif Islam: Kajian Status Belia-belia Felda Bukit Ranum, Kulai, Johor Darul Takzim". Tesis Sarjana Tidak Diterbitkan. Bangi, Selangor: UKM [Universiti Kebangsaan Malaysia].

Ismail, M. Mohd. (2005). Menjadi Belia Cemerlang. Kuala Lumpur: PTS Professional Publishing Sdn Bhd.

Jamali, S. et al. (2010). Pembinaan Sahsiah Remaja: Proses dan Perkembangan. Bangi: Pusat Perkembangan Pelajar UKM [Universiti Kebangsaan Malaysia].

Jamiah, H.M. et al. (2004). "Prinsip Pengukuran Religiositi dan Personaliti Religiositi daripada Perspektif Islam”. Kertas kerja dibentangkan dalam International Seminar on Islamic Though di UKM (Universiti Kebangsaan Malaysia), Bangi, pada tarikh 24-27 Disember.

JPM [Jabatan Perdana Menteri] Malaysia. (1983). Al-Qur'an: Tafsir Pimpinan ar-Rahman. Kuala Lumpur: Jabatan Perdana Menteri.

KBS [Kementerian Belia dan Sukan] Malaysia. (1997). Dasar Pembangunan Belia Negara. Putrajaya: Kementerian Belia dan Sukan. Wujud dalam online pula di: http://www.unescap.org/ esid/hds/youth/youth_malaysia.pdf [diakses di Serdang, Malaysia: 17 Februari 2016].

Keniston, Kenneth. (1971). Youth and Dissent: The Rise of a New Opposition. New York: Harcourt Brace Jovanorich.

Kenny, M.E. \& K.G. Rice. (1995). “Attachment to Parents and Adjustment in Late Adolescent College Students Current Status, Applications, and Future Considerations" dalam The Counseling Psychologist, 23(3), ms.433-456.

Khadijah, H.K. (1994). Meneroka Alam Remaja. Kuala Lumpur: Nurin Enterprise.

Khaidzir, R.V. \& H.H. Hanina. (2010). “Analisis Kecenderungan Penyalahgunaan Bahan dan Faktor Keagamaan: Kajian Kes terhadap Belia di sebuah
IPTA" dalam Malaysia Journal Of Youth Studies, 3, ms.225-236.

KPT [Kementerian Pengajian Tinggi]. Malaysia. (2010). "Buku Perangkaan Pengajian Tinggi 2009". Wujud dalam online di: http://www.mohe. gov.my/web_statistik/perangkaan_2010.pdf [diakses di Serdang, Malaysia: 2 Mac 2016]. Magoon, M.E. \& G.M. Ingersoll. (2006). "Parental Modeling: Attachment and Supervision as Moderators of Adolescent Gambling" dalam Journal of Gambling Studies, 22(1), ms.1-22.

Mahmood, Z. (2008). Famili Harmoni Memupuk Keluarga Bahagia. Shah Alam: Karya Bestari Sdn Bhd.

Mansur, A. Muhd \& M.T. Siti Nordinar. (1992). Psikologi Remaja. Kuala Lumpur: Penerbit Fajar Bakti.

Melati, S. \& H. Zaharah. (2006). "Cabaran IPT dalam Menangani Salah Laku dan Kepincangan Akhlak Mahasiswa: Tinjauan dan Cadangan". Kertas kerja dibentang dalam NASDEC (National Student Development Conference) di Kuala Lumpur, Malaysia, pada tarikh 8-9 August.

Mohamad, Mahathir. (1991). "The Way Forward: Vision 2020". Working paper presented at the launching of Malaysian Business Council in Kuala Lumpur, Malaysia.

Munawar, I. Ahmad. (2009). "Pengaruh Akidah terhadap Penghayatan Akhlak Pelajar-pelajar Sekolah Menengah Kebangsaan di Malaysia”. Tesis Ph.D. Tidak Diterbitkan. Bangi, Selangor: UKM [Universiti Kebangsaan Malaysia].

Munawar, I. Ahmad \& A. Mohd Nor Shahizan. (2011). "Media Penyiaran: Implikasinya dalam Pembentukan Akhlak Penuntut-penuntut Melayu di Sekolah Menengah Kebangsaan di Malaysia" dalam Akademika, 81(3), ms.3-8.

Munawar, I. Ahmad. \& Y. Noranizah. (2012). "Sumbangan Pendidikan dalam Memperkasa Tamadun Bangsa: Perspektif Islam" dalam SOSIOHUMANIKA: Jurnal Pendidikan Sains Sosial dan Kemanusiaan, 5(1), ms.107-122.

Munawar, I. Ahmad, S. Zakaria \& S. Siti Aishah. (2012). "Islam dan Pembentukan Jati Diri Bangsa Melayu” dalam Jurnal Hadhari, Edisi Khas, ms.143-154.

Mustafa, H.D. (1997). Institusi Kekeluargaan Islam. Kuala Lumpur: Dewan Bahasa dan Pustaka.

Nashih, U. Abdullah. (1989). Pedoman Pendidikan Anak-anak dalam Islam. Klang: Klang Book Centre.

Nashih, U. Abdullah. (1998). Pendidikan Anak-anak Menurut Pandangan Islam, Jilid 1. Kuala Lumpur: Penerbit JAKIM [Jabatan Kebajikan Islam Malaysia]. Nashih, U. Abdullah. (2000). Pendidikan Anak-anak Menurut Pandangan Islam, Jilid 2. Kuala Lumpur: Penerbit JAKIM [Jabatan Kebajikan Islam Malaysia]. 
Nasir, O. Mohd. (2010). Falsafah Akhlak. Bangi: Penerbit UKM [Universiti Kebangsaan Malaysia].

Nasir, O. Mohd \& A.B. Ibrahim. (2011). Akidah dan Akhlak Islam. Bangi: Penerbit UKM [Universiti Kebangsaan Malaysia].

Norina, W.H. Wan. et al. (2013). "Pengaruh Media Massa terhadap Penampilan Akhlak Pelajar Islam Potiteknik Malaysia" dalam The Online Journal of Islamic Education, 1, ms.17-27.

Ozman, W.O. Wan Liz. (2000). Gagasan Alaf Baru: Mencetus Kebangkitan Malaysia Membina Keagungan. Batu Caves: Thinker's Library Sdn Bhd.

Paterson, J.E., J. Field \& J. Pryor. (1994). “Adolescents' Perceptions of Their Attachment Relationships with Their Mothers, Fathers, and Friends" dalam Journal of Youth and Adolescence, 23(5), ms.579-600.

Razaleigh, M. \& T. Ahmad Tarmizi. (2010). "Penyelesaian Masalah Belia dari Perspektif Agama" dalam Malaysian Journal of Youth Studies, 3, ms.38-51.

Razali, H. Mohd \& S.G. Sarjit. (2010). "Penyertaan Belia dalam Program Pembangunan Komuniti di Felda Jerangau, Terengganu" dalam Malaysian Journal of Youth Studies, 3, ms.257-275.

Rice, F.P. \& K.G. Dolgin. (2008). The Adolescent Development: Relationship and Culture. Boston: Pearson Education, 12nd edition.

Rohana, S. Siti. (2004). "Pengaruh Faktor Ekologi ke atas Kemurungan Remaja”. Tesis Master Tidak Diterbitkan. Serdang, Selangor: UPM [Universiti Putra Malaysia].

Rozumah, B. (2009). "Utiliti Kerangka Kerja Kontekstual dalam Penganalisisan Pembangunan Manusia" dalam B. Rozumah \& A.T. Mansor [eds]. Pembangunan Manusia dalam Konteks. Kuala Lumpur: Inreach Edition.

Sang, Mok Soon. (2010). Falsafah Pendidikan di Malaysia. Selangor: Penerbitan Multimeia Sdn Bhd.

Sarjit, S.G. \& W.I. Wan Ahmad Amir Zal. (2008). "Perubahan Nilai Budaya Belia Malaysia Menuju Wawasan 2020" dalam Jurnal Pembangunan Belia Malaysia, 1, ms.15-34.

Shahrudin, B., A. Azman \& C.S. Mazlan. (2010). "Belia 1Malaysia: Antara Cabaran dan Harapan" dalam Malaysian Journal of Youth Studies, 2, ms.52-75.

Shakirah, M.A. Noor. (2008). Al-Ghazali and His Theory of the Soul: A Comparative Study. Pulau Pinang. Penerbit USM [Universiti Sains Malaysia].
Shazalina, W.S. Wan Noor. (2009). "Kaitan TingkahLaku Keibubapaan dan Pendidikan Keagamaan oleh Ibu Bapa dengan Moral Pelajar Remaja”. Tesis Sarjana Muda Tidak Diterbitkan. Skudai, Johor: UTM [Universiti Teknologi Malaysia].

Steinberg, L. (2011). Adolescence. New York: McGraw Hill, 9th edition.

Suzane, J. Jas Laile. (2002). Psikologi Kanak-kanak dan Remaja. Shah Alam: Arah Pendidikan Sdn Bhd.

Svensson, Y. et al. (2012). "Peer Selection and Influence of Delinquent Behavior of Immigrant and Non-Immigrant Youths: Does Context Matter?" dalam International Journal of Behavioral Development, 36(3), ms.178-185.

UME [University of Minnesota Extension]. (2005). "Keys to Quality Youth Development". Wujud dalam online di: http://www.extension.umn.edu/ distribution/youthdevelopment/DA6715.html [diakses di Serdang, Malaysia: 28 Disember 2015].

"UNESCO (United Nations for Education, Social and Cultural Organization". Wujud dalam online di: http://www.unesco.org/new/en/social-and-humansciences/themes/youth/ [diakses di Serdang, Malaysia: 17 April 2016].

Yaacob, Abdul Monir. (2007). "Membentuk Keluarga Menerusi Nilai-nilai Kekeluargaan Islam” dalam S. Azrina [ed]. Keluarga Islam: Kemahiran Keibubapaan dan Cabaran Semasa. Kuala Lumpur: MPH Group Publishing \& Institut Kafahaman Islam Malaysia.

Zakaria, S. (2001). Akidah \& Akhlak dalam Kehidupan Muslim. Kuala Lumpur: Utusan Publications \& Distributors Sdn Bhd.

Zakaria, S. (2009). "Manusia Pembina Tamadun: Perspektif Pemikran Islam" dalam Jurnal Hadhari, 1, ms.31-44.

Zakaria, S., I. Ahmad Munawar \& S. Abdul Fatah. (2012). "Pendidikan Menurut Al-Quran dan Sunah serta Peranannya dalam Memperkasa Tamadun Ummah" dalam Jurnal Hadhari, Edisi Khas, ms.7-22.

Zakaria, S., I. Ahmad Munawar \& Y. Noranizah. (2012). "Faktor Pembelajaran Sosial dan Hubungannya dengan Pembentukan Jati Diri” dalam Jurnal Hadhari, Edisi Khas, ms.155-172.

Zulkifli, A.H. et al. (2011). "Hubungan di antara Penglibatan Ibu Bapa dan Pencapaian Akademik Pelajar Miskin di Negeri Selangor" dalam JIAE: Journal of Islamic and Arabic Education, 3(2), ms.31-40. 
ROHANA TAN \& NORHASNI ZAINAL ABIDDIN,

Tinjauan Permasalahan Akhlak Belia

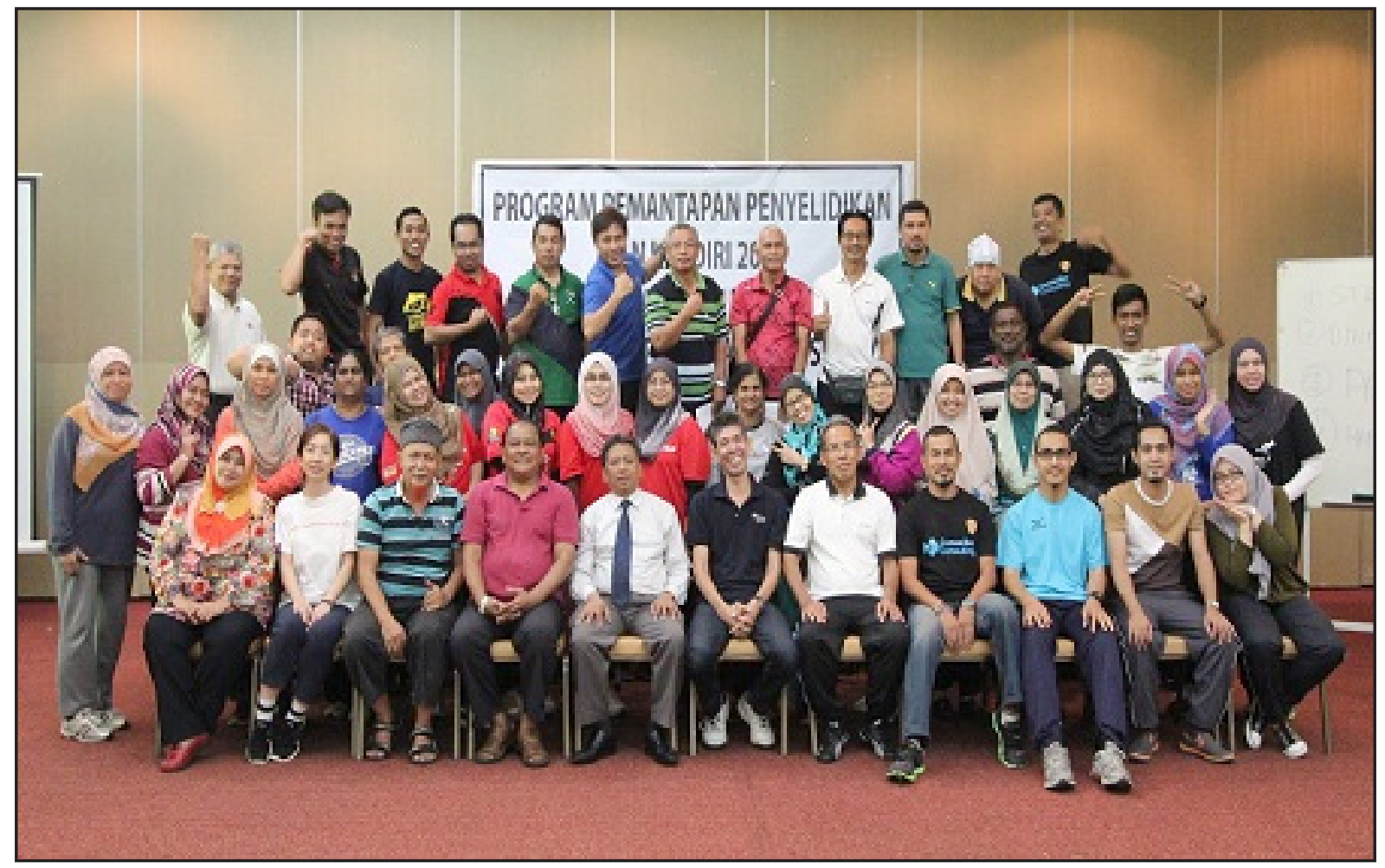

Pembinaan Belia di Institusi Pengajian Tinggi Malaysia

(Sumber: http://www.educ.upm.edu.my, 2/3/2016)

Proses membentuk belia yang berakhlak mulia memerlukan kesepaduan antara pendidikan secara formal dan tidak formal. Proses pembelajaran secara tidak formal yang dilalui bersama masyarakat, khususnya ibu bapa dan rakan sebaya, tidak boleh diambil mudah, malah perlu diberi perhatian serius kerana tempoh masa yang dihabiskan bersama ibu bapa dan rakan sebaya adalah lebih panjang berbanding masa yang diluangkan dalam pendidikan formal. Pembentukan akhlak belia untuk menjadi insan kamil yang cemerlang dan seimbang dari segi intelek dan spiritual adalah proses pendidikan sepanjang hayat dan perlu diberi penekanan selaras dengan pembangunan dan kemajuan negara di Malaysia. 